\title{
Studies on Intrafascicular Cambium in Monocotyledons. V.
}

\author{
BY
}

\author{
AGNES ARBER, D.Sc., F.L.S. \\ (Keddey Fletcher-Warr Student of the University of London).
}

With eight Figures in the Text.

T $\mathrm{N}$ previous papers in this Journal, ${ }^{1}$ I have drawn attention to cases of 1 the occurrence of intrafascicular cambium in a number of monocotyledonous families. Recently the exhaustive researches of Mme GatinAllorge $^{2}$ on the anatomy of the peduncle and flower in the Liliiflorae have demonstrated that the occurrence of intrafascicular cambium may be treated as a universal character of the peduncle of the Liliaceae, Iridaceae, and Amaryllidaceae, and that the enlargement of the bundles observed in these families, at the level at which branches are given off to supply the conducting strands of the flower, is due to the activity of this cambium. In I9I7 Dauphine ${ }^{3}$ published an exquisitely illustrated account of the intrafascicular cambium in Dracaena - a tissue whose existence has already been recognized by Fröken Sigrid Andersson, ${ }^{4}$ but which bears no relation to the meristem responsible for the anomalous secondary thickening so well known in the genus. The work of these authors, and that of Lonay on Ornithogalum, ${ }^{5}$ Chauveaud on Liliaceous and Amaryllidaceous seedlings, ${ }^{6}$ and Queva on the rhizomatous Uvularieae ${ }^{7}$ and the Dioscoreaceae, ${ }^{8}$ in addition to the papers already cited in my previous notes on this subject, make it unnecessary to enlarge further on the existence of intrafascicular cambium in the Liliiflorae; I will now merely mention that I have recently found cambium in the bundles of the very young leaf of Rhipogonum album, R. Br., a member of a genus which is not included in Mme Gatin-Allorge's study. But, before leaving the Liliiflorae, there are one or two points in connexion with the bundles of this Cohort to which I should like to refer. I drew attention in $1919^{9}$ to the fact that in the foliar bundles of a number of Monocotyledons there is a differentiation of the xylem into (i) protoxylem, (ii) primary

1 Arber, A. (1917), (1918), (1919).

3 Dauphiné, A. (1917).

${ }^{6}$ Chauveaud, G. (1911).

${ }^{2}$ Gatin, V. C. (1920).

9 Arber, A. (1919).

4 Andersson, S. (1888).

7 Queva, C. (1907).

5 Lonay, H. (1902).

8 Queva, C. (1894).

[Annals of Botany, Vol. XXXVI. No. CXLII. April, 1922.] 
metaxylem, consisting of elements of large lumen, and (iii) smaller elements, which I interpret as arising secondarily from the intrafascicular cambium. I have since noticed this differentiation in two additional cases-Leucojum aestivum, L. (Amaryllidaceae) and Gladiolus sp. (Iridaceae). In the paper in question I also described and figured certain instances in which the xylem of a lateral branch of a foliar bundle owed its origin exclusively to the secondary xylem of the parent bundle. Recently I have seen a case of this in three other plants-Crocus carpetanus, Boiss. et Reut. (Iridaceae), Asphodelus liburnicus, Scop. (Liliaceae), and Aneilema giganteum, R. Br. (Commelinaceae).

Among the Palms, only two cases of intrafascicular cambium have been hitherto recorded $;^{1}$ to these I can now add three further examples. In serial sections of the shoot apex of Rhapis humilis, Blume, the bundles, both in the young leaves and axis, show cambial activity (Fig. I), and I have also seen the same thing in the plumular leaves of Chamaerops humilis, L., and Areca sapida, Soland.

In the case of the Araceae I recorded in $1918^{2}$ the occurrence of intrafascicular cambium in the rhizome of Acorus Calamus, L., and I have since found this tissue in the very young petiole of Calla palustris, L. (Fig. 2). In $\mathrm{I}_{9 \mathrm{I}_{4}}$ Lignier ${ }^{3}$ described and figured cambium in the petiolar bundle of Arum maculatum, L., stating, however, that he had examined the mature organ only. His account is somewhat intriguing, since, although he describes the cambium as giving rise to phloem alone, his figure shows a differentiation of the wood into protoxylem, then large-lumened metaxylem, and then xylem elements of smaller calibre, which he also regards as part of the primary wood. I should myself have supposed these latter elements to be secondary, since they recall in arrangement and appearance those small xylem elements which I have shown to be of cambial origin in the leaves of Anigozanthos, \&c., ${ }^{4}$ and to which I have again referred in an earlier paragraph of the present paper. In order to try and get further light on the nature of these elements in Arum, I have studied microtome sections of apical buds, and hand sections of older leaves of Aruim italicum, Mill., a species closely related to $A$. maculatum. These sections show that, in the bundles of the petiole and midrib of the very young leaf, there is a radial seriation involving most of the elements between the protoxylem and protophloem. This stage is seen in Fig. $3 \mathrm{~A}$, which was drawn from a leaf so young that the petiole was only about $0.7 \mathrm{~mm}$. in diameter. In the bundles of the midrib and petiole of the mature leaf (Fig. 3 B) the protoxylem is followed by a few large elements $(m . x$.$) , which$ I take to be primary metaxylem ; to these again succeed a number of small elements $\left(x_{\cdot_{2}}\right)$, whose seriation in radial files, which continue into the

\footnotetext{
1 For references see Arber, A. (1917).

3 Lignier, O. (1914).
}

2 Arber, A. (1918).

4 Arber, A. (1919). 


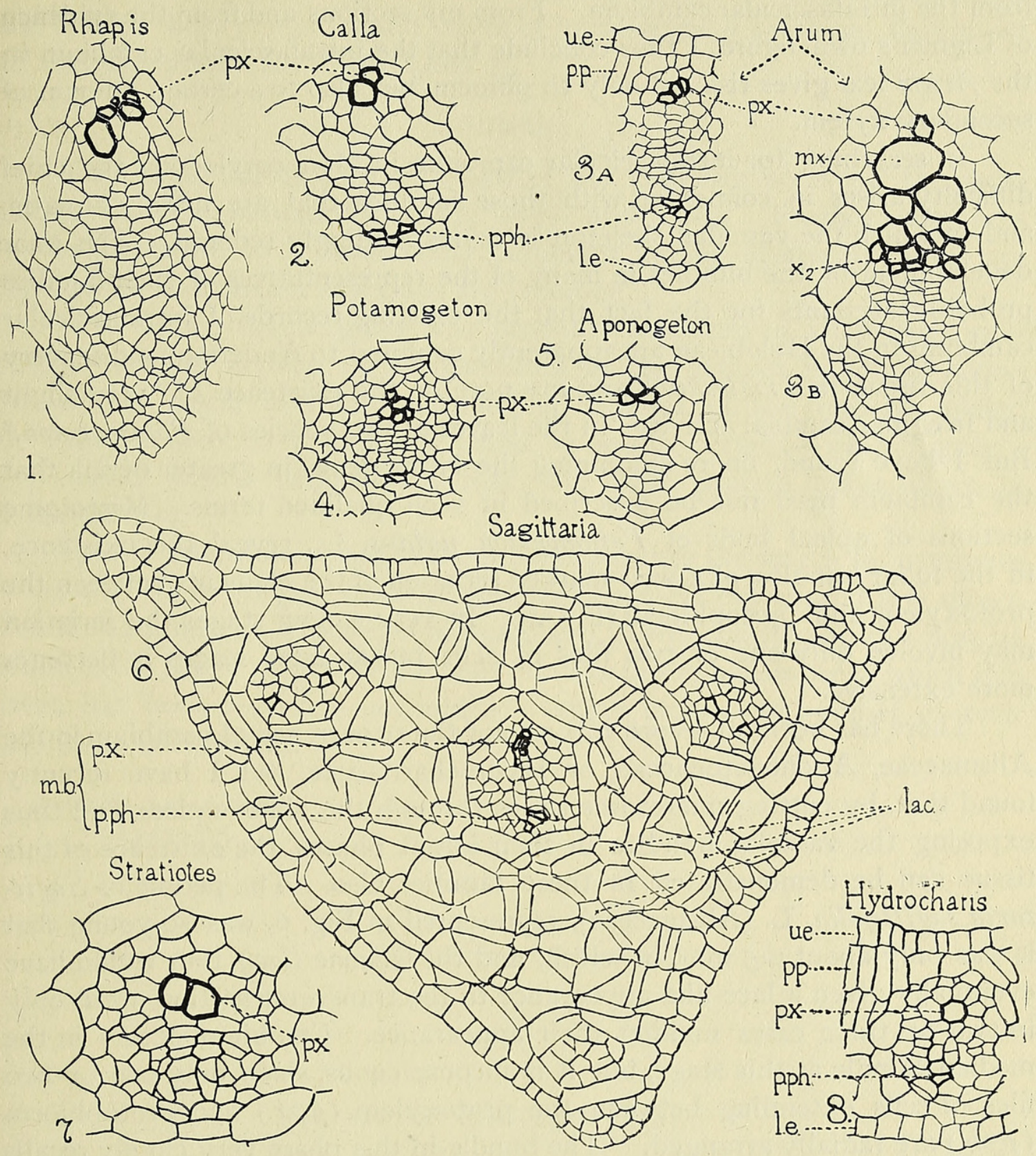

Figs. I-8. (Lettering throughont as follows : p.x., protoxylem; p.ph., protophloem ; p.p., palisade parenchyma ; u.e., upper epidermis ; l.e., lower epidermis.) Fig. I, Rhapis humilis, Blume, bundle from transverse section of stem close to apex $(\times 318)$. Fig. 2, Calla palustris, L., bundle from transverse section of petiole of very young leaf $(\times 3$ I 8$)$. Fig. 3, Arum italicum, Mill. ; Fig. 3 A, median bundle from transverse section of lamina of very young leaf ( $x$ I 93); Fig. 3 B, lateral bundle from transverse section of petiole of older leaf $\left(x \mathrm{I}_{93}\right) ; m . x_{\text {. }}$, primary metaxylem; $x_{._{2}}$, secondary xylem. Fig. 4, Potamogeton natans, L., lateral bundle from transverse section of very young petiole $(\times 318)$. Fig. 5, Aponogeton distachyum, Thunb, principal bundle from transverse section of very young inflorescence axis $(\times 318)$. Fig. 6, Sagittaria sagittifolia, L., transverse section of very young petiole ; m.b., median bundle ; lac., lacunae, of which only three are yet visible ( $\times$ I 93). Fig. 7 , Stratiotes aloides, L., bundle from transverse section of base of very young leaf $(x 318)$. Fig. 8 , Hydrocharis Morsus-ranae, L., median bundle from transverse section of limb of very young leaf $(\times 318)$. 
secondary phloem, seem to me to make it impossible to doubt their origin from the intrafascicular cambium. From my sections and from the evidence of Lignier's own figure, I thus conclude that the intrafascicular cambium in the Arum leaf gives rise not only to phloem, but also to a certain amount of secondary xylem.

In searching for intrafascicular cambium in Monocotyledons, the chief difficulty arises in connexion with those families that are mainly aquatic, and in which the vascular skeleton is correspondingly reduced. The poor development of the bundles in many of the representatives of such families probably accounts for the fact that the existing records of intrafascicular cambium in the Helobieae are apparently confined to Andersson's discovery of this tissue in Triglochin,' and my note on the existence of 'very slight and irregular cambial activity' in the leaves of two species of Potamogeton. ${ }^{2}$ But I have found, on re-examining the latter genus in greater detail, that the cambium need not be described in such qualified terms. Microtome sections of apical buds of Potamogeton natans, L., reveal the existence, in the foliar bundles, of a well-marked seriation of the elements between the protoxylem and protophloem (Fig. 4). In very young stages the seriation may involve only one or two files of cells, but at later stages it becomes more extensive.

There has been no record hitherto of the occurrence of cambium in the Alismaceae, Aponogetonaceae, or Hydrocharitaceae, but I have recently found that, by cutting microtome series through the shoot apices, and thus exposing the vascular bundles in their initial phases, the existence of this tissue can be demonstrated in these families also. The petiole of Sagittaria sagittifolia, L. (Alismaceae), represented in Fig. 6, was so young that it was only about $0.5 \mathrm{~mm}$. in width, and the lacunae (lac.), that would have eventually given a lace-like appearance to the transverse section, were only in two or three cases making their appearance. Cambium occurs in the median bundle at this stage, but it is inconspicuous, since only one or two files of cells extending between the protoxylem $(p \cdot p x$.$) and protophloem$ $(p . p h$.$) are radially arranged. The bundle in this phase very closely recalls$ Queva's description of the median vascular strand of the very young leaf in the Liliaceous genera Uvularia and Tricyrtis. ${ }^{3}$ The cambial activity in Sagittaria is extremely ephemeral, and one may search in vain for any sign of it in older petioles.

On cutting serial sections through the apical bud of Aponogeton distachyum, Thunb. (Aponogetonaceae), I found that there is a distinct development of intrafascicular cambium in the rudimentary inflorescence axis; that to which the bundle drawn in Fig. 5 belonged, was so young as to be only $0.3 \mathrm{~mm}$. in diameter.

In the case of the Hydrocharitaceae, I examined serial sections through
1 Andersson, S. (1888).
2 Arber, A. (1918).
s Queva, C. (1907). 
the shoot apex of Hydrocharis Morsus-ranae, L., and Stratiotes aloides, L., and in both these plants I found traces of intrafascicular cambium, though on an inconspicuous scale (Figs. 8 and 7).

\section{SUMMARY.}

This paper forms a continuation of my previous notes on the same subject in this Journal for I9I7, I918, and 1919. Further references in the literature to intrafascicular cambium among Monocotyledons are considered, and certain new cases are recorded.

It is shown that Lignier was probably mistaken in attributing only ${ }^{\circ}$ phloem-forming activity to the cambium in the petiolar bundle of Arum maculatum, since, in the corresponding bundles of the closely related A. italicum, secondary xylem is found to be also formed-while Lignier's own figure leaves little doubt that the same process takes place in A. maculatum.

Special attention is paid in the present paper to the search for cambium in the slightly developed vascular bundles of the Helobieae, and it is shown that the Alismaceae, Aponogetonaceae, and Hydrocharitaceae can now be added to the list of monocotyledonous families in some member of which this tissue has been observed-an addition which brings the number of such families to twenty-two.

BALFOUR LABORATORY, CAMBRIDGE.

\section{ListS OF MEMOIRS CITED.}

ANDERSSON, S. (1888): Om de primära kärlsträngarnes utveckling hos monokotyledonerna. Bihang till k. Svenska Vet.-Akad. Handlingar, Bd. xiii, I 88,8, Afd. III, No. I 2, 23 pp., two plates. Arber, A. (1917) : On the Occurrence of Intrafascicular Cambium in Monocotyledons. Ann. Bot., vol. xxxi, 1917, pp. $4 \mathrm{I}-45$, three text-figures.

- (1918) : Further Notes on Intrafascicular Cambium in Monocotyledons. Ann. Bot., vol. xxxii, I9I8, pp. 87-9, four text-figures.

(1919): Studies on Intrafascicular Cambium in Monocotyledons (III and IV). Ann. Bot., vol. xxxiii, 1919, pp. 459-65, seven text-figures.

Chauveaud, G. (1911): L'appareil conducteur des plantes vasculaires et les phases principales de son évolution. Ann. d. sci. nat., Bot., sér. ix, t. xiii, I9I I, pp. I I 3-438, 2 I 8 text-figures.

DAUPHiné, A. (1917): Sur la valeur des formations libéro-ligneuses supplémentaires chez certaines Monocotylédones. Ann. d. sci. nat., Bot., sér. ix, t. xx, I9I 7, pp. 309-14, one plate, two text-figures.

Gatin, V. C. (1920): Recherches anatomiques sur le pédoncule et la fleur des Liliacées. Rev. Gén. de Bot., t. xxxii, 1920, pp. 369-437, 460-528, 561-591, sixty text-figures. 
256 Arber.-Studies on Intrafascicular Cambium. $V$.

Lignier, O. (1914): Nouveau cas de cambium chez les Monocotylédones. Ass. franç. pour l'Avanc. des Sci., Compte rendu Session 43, Le Havre, Paris, I9I5 (for I9I4), pp. 487-90, one text-figure.

Lonay, H. (1902): Recherches anatomiques sur les feuilles de l'Ornithogalum caudatum, Ait. Mém. de la Soc. Roy. des Sci. de Liége, sér. iii, t. iv, No. 9, I902, pp. I-82, five plates.

Queva, C. (1894): Recherches sur l'anatomie de l'appareil végétatif des Taccacées et des Dioscorées. Mém. de la Soc. des Sci. de Lille, I 894,457 pp., eighteen plates.

(1907) : Contributions à l'anatomie des Monocotylédonées. II. Les Uvulariées rhizomateuses. Beih. zum Bot. Centralbl., Bd. xxii, Abt. 2, I907, pp. 30-77, forty-nine text-figures. 


\section{$2 \mathrm{BHL}$ Biodiversity Heritage Library}

Arber, Agnes Robertson. 1922. "Studies on intrafascicular cambium in monocotyledons. V." Annals of botany 36, 251-256. https://doi.org/10.1093/oxfordjournals.aob.a089804.

View This Item Online: https://www.biodiversitylibrary.org/item/234428

DOI: https://doi.org/10.1093/oxfordjournals.aob.a089804

Permalink: https://www.biodiversitylibrary.org/partpdf/319040

\section{Holding Institution}

Smithsonian Libraries

\section{Sponsored by}

Biodiversity Heritage Library

\section{Copyright \& Reuse}

Copyright Status: Not in copyright. The BHL knows of no copyright restrictions on this item.

This document was created from content at the Biodiversity Heritage Library, the world's largest open access digital library for biodiversity literature and archives. Visit BHL at https://www.biodiversitylibrary.org. 